\title{
DESAIN BUKU CERITA ANAK BERLATAR KEGIATAN KEPRAMUKAAN PENGGALANG
}

\author{
Sifa Fauziah ${ }^{1}$, Wagiran ${ }^{2}$ \\ Universitas Negeri Semarang ${ }^{1,2}$ \\ fauziahsyifa284@yahoo.com ${ }^{1}$, wagiran@mail.unnes.ac.id ${ }^{2}$
}

\begin{abstract}
ABSTRAK
Rendahnya minat baca anak termasuk membaca buku cerita disebabkan kurangnya variasi buku-buku cerita anak yang beredar di pasaran. Salah satu upaya untuk menambah variasi buku cerita anak adalah dengan menggunakan latar cerita kegiatan siswa saat mengikuti Kepramukaan Penggalang. Tujuan penelitian ini yaitu untuk mengetahui kualitas buku cerita anak yang sudah ada, mengetahui kebutuhan akan cerita anak berlatar kegiatan Kepramukaan Penggalang, dan mendesain buku cerita anak berlatar kegiatan Kepramukaan Penggalang. Data dikumpulkan melalui teknik observasi, wawancara, dan penyebaran angket. Hasil dari penelitian ini berupa buku cerita anak berlatar kegiatan Pramuka Penggalang. Buku cerita yang siswa inginkan adalah buku cerita dengan tema petualangan, menggunakan bahasa yang komunikatif, disertai ilustrasi menarik yang dapat menggambarkan isi cerita, dan didukung oleh perpaduan warna terang yang juga dapat menarik perhatian siswa. Desain buku cerita anak berlatar kegiatan Kepramukaan Penggalang disusun berdasarkan angket kebutuhan siswa.
\end{abstract}

Kata kunci: buku, cerita anak, kepramukaan penggalang

\section{ABSTRACT}

Children's low interest in reading storybook is caused by the lack of variety of books in the markets. One of the effort to increase the variety of books is to use the settings of a Scout's Raiser activity. The aim of this study is to find out the quality of the books in the markets, the needs of storybooks based on the Scout's Raiser activity, and to design a storybook based on the setting of Scout's Raiser Activity. The data was collected through observation, interview, and questionaires. The result of the study was a children's storybook with a Scout's Raiser activity as the background of the story. The students want a storybook about adventure, which is using a communicative language, contains illustration that describe the story, and also a cheerful color that can attract them. The design of the storybook based on the settings of Scout's Raiser activity was arranged based on the questionaires.

Keywords: books, children's story, scout's raiser

\section{PENDAHULUAN}

Membaca adalah kunci keberhasilan anak. Namun, pada kenyataannya anak lebih suka menonton televisi dan bermain gadget dari pada membaca. Banyak cara yang dilakukan oleh pemerintah untuk meningkatkan minat baca siswa. Salah satunya dengan mengeluarkan Permendikbud No . 23 Tahun 2015 tentang Penumbuhan Budi Pekerti yaitu mewajibkan siswa untuk membaca buku selain buku pelajaran selama sepuluh menit sebelum kegiatan pembelajaran dimulai.

Menurut Nurgiyantoro (2005:46) budaya membaca harus ditumbuhkan sejak dini, dan itu sangat efektif dimulai dengan bacaan sastra. Peran bacaan sastra selain membentuk kepribadian anak, juga menumbuhkan dan mengembangkan rasa ingin dan mau membaca, yang akhirnya membaca tidak terbatas hanya pada bacaan sastra. Sastra juga dapat memotivasi 
anak untuk mau membaca. Sejalan dengan hal tersebut, Sumardi (2012:103) menyatakan bahwa menumbuhkan budaya baca atau kebiasaan membaca harus dimulai sejak kanak-kanak. Untuk itu, diperlukan sarana utamanya yaitu cerita anak-anak yang bermutu dalam jumlah yang besar, baik jumlah eksemplarnya maupun jumlah judulnya.

Rendahnya minat baca anak termasuk membaca buku cerita disebabkan buku-buku yang beredar di pasaran kurang variatif, umumnya buku-buku yang beredar merupakan bukubuku seri fabel, seri dongeng dunia, dan seri fantasi lainnya. Beberapa hal tersebut menjadi faktor rendahnya minat baca anak terhadap buku cerita. Oleh karena itu, perlu adanya buku yang dapat meningkatkan minat baca anak terhadap buku cerita, di antaranya dengan menggunakan latar cerita kegiatan siswa dalam mengikuti ekstrakurikuler Kepramukaan Penggalang. Nilai-nilai moral yang bersumber dari Dasa Darma Pramuka dapat diintegrasikan melalui sebuah cerita.

Buku cerita merupakan salah satu media untuk menanamkan nilai-nilai moral yang terdapat dalam kegiatan Pramuka. Selain itu, melalui buku cerita, anak akan mengenal kegiatan-kegiatan yang terdapat dalam Pramuka. Buku cerita juga dapat dijadikan sebagai media pembelajaran di sekolah sekaligus untuk meningkatkan kegemaran siswa dalam membaca.

Masalah yang dibahas dalam penelitian ini meliputi bagaimana kualitas buku cerita anak yang beredar di pasaran, bagaimana kebutuhan akan buku cerita anak berlatar kegiatan Kepramukaan Penggalang dan bagaimana desain buku cerita anak berlatar kegiatan Kepramukaan Penggalang. Tujuan penelitian ini adalah untuk mengetahui kualitas buku cerita anak yang beredar di pasaran, mengetahui kebutuhan akan buku cerita anak berlatar kegiatan Kepramukaan Penggalang dan mendesain buku cerita anak berlatar kegiatan Kepramukaan Penggalang.

Penelitian yang relevan dengan penelitian ini antara lain dilakukan oleh Morris et al. (2000), Amour (2003), Andini (2009), Sulistyaningsih (2010), Prasandha (2012), Hariyanti (2013), Riantini (2014), dan Wijayanti (2015). Kedudukan penelitian ini adalah untuk melanjutkan dan melengkapi penelitian-penelitian yang sudah ada, peneliti melakukan sebuah penelitian yang akan menghasilkan produk berupa buku pengayaan. Buku ini merupakan buku cerita anak yang berlatar kegiatan Kepramukaan Penggalang. Diharapkan hasil penelitian ini akan bermanfaat dalam mengembangkan buku cerita anak yang dapat mendidik anak menjadi insan yang berbudi luhur. 
Beberapa teori terkait cerita anak disampaikan oleh Rampan (2012:73), Musfiroh (2008:81-97), dan Sumardi (2012:104). Dari ketiga pendapat tersebut dapat disimpulkan bahwa karakteristik atau ciri-ciri cerita anak yang unggul mengandung nilai personal dan nilai pendidikan bagi pembacanya (kalangan anak-anak). Cerita anak mengandung nilai personal apabila mampu memberikan kesenangan, menawarkan narasi sebagai cara bernalar, mengembangkan imajinasi, memberikan beraneka ragam pengalaman, mengembangkan kemampuan pandangan dari dalam (insight opinion) terhadap perilaku manusia, dan menghadirkan pengalaman universal. Cerita anak mengandung nilai pendidikan apabila mampu mengembangkan kemampuan berbahasa, mengembangkan kemampuan membaca, mengembangkan kemampuan bercerita, menunjang kemampuan menulis, dan memperkenalkan kekayaan sastra anak. Berdasarkan karakteristik cerita anak tersebut, buku cerita anak termasuk dalam kategori buku pengayaan kepribadian.

Beberapa pendapat tentang buku pengayaan disampaikan oleh Muslich (2008), Kusmana (2008), Arifin dan Adi (2009:89), serta Puskurbuk (2008:7). Dari beberapa pendapat tersebut, dapat disimpulkan bahwa ciri-ciri buku pengayaan kepribadian adalah (1) materi bersifat faktual dan dapat pula rekaan, (2) isi buku dapat meningkatkan dan memperkaya kualitas kepribadian, sikap, atau pengalaman batin pembaca, dan (3) penyajian dapat dilakukan dalam bentuk narasi, puisi, dialog, atau gambar. Sesuai dengan isi materi yang disajikan, maka klasifikasi buku pengayaan keperibadian terdiri atas buku pengayaan kepribadian jenis fiksi dan jenis nonfiksi.

\section{METODE PENELITIAN}

Penelitian ini menggunakan pendekatan Research and Development (R\&D). Menurut Sukmadinata (2013:164) penelitian dan pengembangan atau Research and Development (R\&D) adalah suatu proses atau langkah-langkah untuk mengembangkan suatu produk baru atau menyempurnakan produk yang telah ada, yang dapat dipertanggungjawabkan. Sugiyono (2008:298) mengemukakan langkah-langkah penelitian R\&D meliputi (1) potensi dan masalah, (2) pengumpulan data, (3) desain produk, (4) validasi desain, (5) revisi desain, (6) uji coba produk, (7) revisi produk, (8) uji coba pemakaian, (9) revisi produk, dan (10) produksi masal. Prosedur dalam penelitian ini yaitu (1) potensi dan masalah yang meliputi mencari sumber pustaka dan hasil penelitian yang relevan, melakukan kajian literatur buku cerita anak yang telah ada; (2) mengumpulkan data yang diperoleh dari menganalisis angket kebutuhan dan 
wawancara yang dilakukan pada siswa dan guru; dan (3) membuat desain awal buku cerita anak berdasarkan analisis angket kebutuhan dan wawancara.

Data yang akan dikumpulkan dalam penelitian ini di antaranya data kualitas buku cerita anak yang sudah ada dan data mengenai kebutuhan siswa serta guru SMP di Semarang terhadap buku cerita anak berlatar kegiatan Kepramukaan Penggalang. Sumber data yang diperoleh untuk mengetahui kualitas buku cerita anak yang sudah ada bersumber dari perpustakaan didua SMP yang berbeda yaitu SMP Negeri 15 Semarang dan SMP Negeri 25 Semarang. Selain itu, data kualitas buku cerita anak yang sudah ada juga didapat dari observasi ke toko buku Gramedia dan Toga Mas Semarang. Data kedua yaitu kebutuhan siswa dan guru terhadap buku cerita anak berlatar kegiatan Kepramukaan Penggalang diperoleh dari tiga guru bahasa Indonesia dan siswa-siswi dari tiga sekolah yang berbeda, antara lain SMP Negeri 15 Semarang, SMP Negeri 25 Semarang, dan SMP Islam Al-Madina Semarang.

Teknik pengumpulan data yang digunakan untuk mendapatkan data pertama yaitu dengan angket observasi. Angket tersebut digunakan sebagai dasar mengidentifikasi potensi masalah, yaitu belum adanya buku cerita anak berlatar kegiatan Kepramukaan Penggalang. Peneliti melakukan pengecekan kondisi buku cerita anak yang terdapat didua perpustakaan sekolah dan dua toko buku di Semarang. Data kedua diambil menggunakan angket dan wawancara. Angket untuk data kedua ditujukan untuk mengetahui kebutuhan siswa dan guru terhadap buku cerita anak berlatar kegiatan Kepramukaan Penggalang. Wawancara dilakukan pada guru dan siswa.

Bentuk instrumen dalam penelitian ini menggunakan instrumen nontes. Instrumen nontes yang digunakan berupa angket observasi, lembar wawancara, angket kebutuhan guru, dan angket kebutuhan siswa. Instrumen yang digunakan untuk mendapatkan data mengenai buku bacaan cerita anak yang sudah beredar di lapangan berupa angket chek list. Angket tersebut berisi keterangan gambaran buku yang ditemukan, dengan pilihan jawaban $Y a$ atau Tidak. Pada pengambilan data kebutuhan siswa dan guru, instrumen yang digunakan yaitu angket kebutuhan. Angket tersebut mempertanyakan hal-hal yang terkait dengan bentuk fisik serta materi buku cerita anak yang akan dikembangkan.

Teknik analisis data yang digunakan dalam penelitian ini terdiri atas teknik analisis data observasi, data wawancara, data kebutuhan siswa dan guru. Teknik yang digunakan untuk menganalisis data hasil observasi dan angket kebutuhan siswa dan guru adalah deskriptif kualitatif. Pelaksanaan analisis data kebutuhan siswa dan guru dilakukan dengan mengidentifikasi data kebutuhan siswa dan guru terhadap buku cerita anak berlatar kegiatan 
Kepramukaan Penggalang dari angket yang telah diberikan.

\section{HASIL DAN PEBAHASAN}

\section{Hasil}

Hasil penelitian yang dipaparkan dalam bab ini meliputi tiga hal, yaitu (1) kualitas buku cerita anak yang sudah ada, (2) kebutuhan akan buku cerita anak berlatar kegiatan Kepramukaan Penggalang, dan (3) desain buku cerita anak berlatar kegiatan Kepramukaan Penggalang.

\section{Kualitas Buku Cerita Anak yang Sudah Ada}

Observasi dilakukan diempat tempat yaitu SMP Negeri 15 Semarang, SMP Negeri 25 Semarang, toko buku Toga Mas, dan toko buku Gramedia Semarang. Berikut deskripsi hasil observasi tersebut. Berdasarkan hasil observasi didua perpustakaan dan dua toko buku di Semarang, diperoleh hasil bahwa tidak ditemukan buku cerita anak yang menggunakan latar kegiatan Kepramukaan Penggalang yang mengandung pesan moral dari Dasa Darma Pramuka. Dari keempat tempat observasi tersebut, banyak ditemukan buku-buku cerita anak yang berisi fabel dan dongeng, dan hanya satu tempat observasi yang terdapat buku cerita anak yang menggunakan bahasa sesuai dengan perkembangan anak, komunikatif dan mudah dipahami oleh anak dengan ejaan, tanda baca, kosakata, kalimat, dan paragraf sesuai dengan kaidah bahasa Indonesia.

Dari dua sekolah dan dua toko buku, hanya buku-buku yang terdapat di toko buku yang memiliki alur sederhana. Buku cerita anak yang terdapat di perpustakaan merupakan buku lama yang masih menggunakan alur yang kompleks sehingga dapat menyulitkan anak dalam memahami buku cerita tersebut. Sedangkan di toko buku terdapat banyak buku cerita anak dengan alur cerita yang lebih sederhana. Berdasarkan hasil observasi, umumnya sampul buku cerita anak belum menarik dengan perpaduan warna yang tidak sesuai dengan sasaran pembaca, dan jenis huruf serta ukuran huruf tidak sesuai dengan sasaran pembaca. Selain itu, dari empat tempat observasi tersebut, hanya dua tempat yang terdapat buku cerita anak dengan ilustrasi yang mewakili dan memperjelas isi buku.

\section{Kebutuhan akan Buku Cerita Anak Berlatar Kegiatan Kepramukaan Penggalang}

Berdasarkan angket kebutuhan siswa, diperoleh hasil bahwa buku cerita anak berlatar kegiatan Kepramukaan Penggalang yang mereka inginkan adalah buku cerita petualangan saat 
mengikuti kegiatan Pramuka yang disertai gambar berwarna, hal ini berdasarkan hasil angket dari 93 siswa (91,2\%). Selain itu, 64 (62,7\%) siswa menjawab judul yang sesuai untuk buku cerita anak yang akan dikembangkan oleh peneliti adalah Asyiknya Ikut Pramuka, dan 64 siswa $(62,7 \%)$ memilih gambaran singkat isi buku yang sesuai untuk mengisi sampul belakang buku cerita anak.

Dari aspek bahasa, $71(69,6 \%)$ siswa menyarankan agar menggunakan bahasa Indonesia sehari-hari atau komunikatif. Selain bahasa, dari 102 siswa, 75 siswa $(73,5 \%)$ menginginkan jenis huruf yang digunakan adalah Comic Sans Ms. Selain itu, 59 siswa (57,8\%) menginginkan agar ukuran huruf untuk isi buku cerita adalah 12. Ketebalan buku yang diinginkan oleh sebagian besar siswa adalah 60-90 halaman. Ketebalan buku antara 60-90 halaman ini dipilih oleh 61 siswa (59,8\%). Harapan siswa terhadap buku cerita anak berlatar kegiatan Kepramukaan Penggalang dapat menambah koleksi buku bacaan siswa, dengan bahasa yang mudah dipahami, kemasan yang menarik, warna, ilustrasi gambar, dan isi cerita yang menarik, serta ketebalan buku yang disesuaikan.

Berdasarkan angket kebutuhan guru, dapat dideskripsikan bahwa buku cerita anak berlatar kegiatan Kepramukaan Penggalang belum pernah ada di pasaran, hal ini berdasarkan jawaban dari tiga guru yang menyatakan bahwa mereka belum pernah menemukan buku cerita anak yang menggunakan latar kegiatan Kepramukaan Penggalang. Dua dari tiga guru memilih Asyiknya Ikut Pramuka yang cocok untuk dijadikan judul buku cerita anak berlatar kegiatan Kepramukaan Penggalang. Buku cerita anak akan lebih menarik dan mudah dipahami jika disertai ilustrasi gambar. Hal tersebut berdasarkan hasil pilihan ketiga guru yang memilih untuk disertai ilustrasi gambar pada isi dan sampul buku cerita anak dengan warna yang beragam. Dua dari tiga guru memilih agar sampul belakang buku cerita anak berlatar kegiatan Kepramukaan Penggalang diisi gambaran singkat isi buku.

Dari aspek bahasa, para guru menyarankan agar menggunakan bahasa yang komunikatif yang dapat dengan mudah dipahami oleh siswa jika mereka membaca cerita tersebut. Jenis huruf (font) yang sesuai untuk judul dan isi buku cerita anak yaitu Comic Sans $M S$. Sementara itu, ukuran huruf yang sesuai untuk penulisan isi buku cerita anak semua guru memilih ukuran 12 untuk bagian isi buku cerita. Selain jenis dan ukuran huruf, berdasarkan hasil angket dua orang guru memilih ketebalan buku yang sesuai untuk buku cerita anak yaitu sekitar 60-90 halaman. Untuk ukuran buku cerita anak semua guru setuju dan memilih untuk menggunakan kertas ukuran A5 yang digunakan dalam penyusunan buku cerita anak berlatar kegiatan Kepramukaan Penggalang. 
Guru mengharapkan agar penyusunan buku cerita anak berlatar kegiatan Kepramukaan Penggalang ini dikemas secara ringan dan menarik, sehingga anak akan mudah memahami nilai moral yang diajarkan pada setiap bagian cerita sekaligus meningkatkan minat baca siswa dan tentunya mengenalkan Pramuka melalui cara yang disukai oleh siswa yaitu buku cerita. Selain itu, buku cerita anak berlatar kegiatan Kepramukaan Penggalang juga dapat menambah pegangan guru atau pendidik dalam mengajarkan nilai-nilai karakter pada siswa.

\section{Desain Buku Cerita Anak Berlatar Kegiatan Kepramukaan Penggalang}

Desain buku cerita anak berlatar kegiatan Kepramukaan Penggalang dikembangkan berdasarkan hasil angket kebutuhan siswa dan guru dengan memperhatikan prinsip pengembangan. Komponen buku cerita anak dibuat berdasarkan teori Arifin dan Adi (2009:93), anatomi atau bagian-bagian buku terdiri atas (1) bagian luar pada buku dan (2) bagian dalam pada buku.

Bagian luar pada buku cerita anak berlatar kegiatan Kepramukaan Penggalang terdiri atas (1) sampul depan, (2) tulisan punggung dan (3) sampul belakang. Ukuran buku adalah A5 $(14,8 \mathrm{~cm}$ x $21 \mathrm{~cm})$ sesuai dengan hasil angket kebutuhan siswa dan guru. Bahan sampul buku berupa kertas jenis Daff dengan dominasi warna biru muda dan cokelat. Sampul depan berisi judul utama, anak judul, gambar ilustrasi, dan nama pengarang. Judul utama buku adalah 'Asyiknya Ikut Pramuka' ditulis menggunakan jenis huruf Crayon Crumble ukuran 51. Anak judul buku yaitu 'Ikuti Serunya Petualangan Kami dalam Kegiatan Pramuka Penggalang' ditulis dengan menggunakan jenis huruf Dk Lemon Yellow dengan ukuran 24. Tulisan punggung berisi judul utama Asyiknya Ikut Pramuka dan nama pengarang. Sampul belakang berisi penggalan dialog yang terdapat pada salah satu judul cerita. Bagian tersebut ditulis menggunakan jenis huruf Chinacat Regular ukuran 17 spasi 1.5 .

Bagian dalam pada buku cerita anak terdiri atas (1) praisi, (2) isi, dan (3) pascaisi. Praisi memuat bagian-bagian depan buku meliputi halaman prancis, halaman judul utama, halaman hak cipta, halaman prakata, dan halaman daftar isi. Bagian isi buku terdiri atas lima judul cerita yaitu (1) Taklukkan Rintangan Dianpinru, (2) Jambore dan Rinduku untuk Mama, (3) Petualanganku di Perkemahan Bakti, (4) Jelajah Alam (Cintai dan Lindungi), (5) Lomba Tingkat II, Pasti Bisa!. Jenis huruf Comic Sans MS dipilih untuk menuliskan teks cerita dengan ukuran 11 spasi 1,5. Pascaisi dalam buku cerita anak ini berupa biodata penulis. 


\section{Pembahasan}

Berdasarkan hasil angket kebutuhan siswa dan guru, buku cerita anak berlatar kegiatan Kepramukaan Penggalang disertai ilustrasi yang dapat mempermudah anak dalam memahami isi cerita. Hal ini sejalan dengan pendapat Sugihastuti (2013:82-83) yang mengatakan bahwa menikmati ilustrasi cerita anak-anak adalah menyimak fakta cerita. Kelengkapan cerita dapat ditangkap pembaca (anak-anak) sejauh ilustrasi bisa mendukungnya. Sugihastuti juga menjelaskan bahwa ilustrasi yang baik yaitu ilustrasi yang mempunyai daya pesan dan imajinasi sesuai dengan isi cerita.

Bentuk buku juga disesuaikan dengan hasil angket kebutuhan siswa terhadap desain produk buku cerita anak berlatar kegiatan Kepramukaan Penggalang. Bentuk buku dirancang dengan ukuran A5 (14,8 cmx21 cm) dengan jenis huruf Times New Roman, Comic Sanc MS, dan Calibri. Berdasarkan teori yang disampaikan oleh Arifin dan Adi (2009:93) anatomi sebuah buku dikelompokkan menjadi dua bagian yaitu bagian luar pada buku dan bagian dalam pada buku. Bagian luar pada buku merupakan bagian buku yang terdiri atas sampul depan, tulisan punggung, dan sampul belakang. Pada bagian sampul depan terdapat judul utama, anak judul, nama penulis, dan ilustrasi.

Wibowo (2013:163) menyatakan bahwa warna menentukan respon pembaca, warna adalah hal yang paling utama dilihat oleh pembaca, terutama background. Perpaduan warna terang atau warna muda digunakan dalam cover atau sampul depan buku cerita anak dengan tujuan agar dapat menarik minat anak terhadap buku tersebut. Hal ini juga sejalan dengan pernyataan Wibowo (2013:150), warna-warna muda seperti kuning muda, hijau muda, merah jambu, biru cerah, dan coklat cerah memberi kesan ceria yang berjiwa muda.Menurut Arifin dan Adi (2009:93) tulisan punggung merupakan bagian kedua dari bagian luar buku. Tulisan punggung pada buku cerita anak ini berisi judul buku dan nama penulis. sampul belakang buku cerita anak berlatar kegiatan Kepramukaan Penggalang berisi sinopsis salah satu judul cerita. Bagian dalam yang terdapat pada buku dimulai dari praisi, isi, dan pascaisi. Halaman praisi buku cerita anak ini memuat halaman prancis, halaman judul utama, halaman hak cipta, halaman prakata, dan daftar isi. Setelah praisi, bagian buku selanjutnya adalah isi (text matter).

Arifin dan Adi (2009:102) memaparkan bahwa bagian isi merupakan bagian utama buku. Seperti yang sudah dipaparkan sebelumnya, dalam buku cerita anak berlatar kegiatan Kepramukaan Penggalang ini terdiri atas lima judul cerita. Judul cerita yang pertama yaitu Taklukkan Rintangan Dianpinru, kedua yaitu Jambore dan Rinduku untuk Mama, judul ketiga yaitu Petualanganku di Perkemahan Bakti, judul keempat yaitu Jelajah Alam (Cintai dan 
Lindungi), dan judul terakhir yaitu Lomba Tingkat II, Pasti Bisa!. Bagian terakhir buku menurut Arifin dan Adi (2009:102) adalah pascaisi. Bagian ini merupakan bagian pelengkap atau tambahan setelah isi buku. Pascaisi dalam buku cerita anak berlatar kegiatan Kepramukaan Penggalang ini memuat biografi singkat penulis.

\section{SIMPULAN}

Berdasarkan hasil penelitian dan pembahasan, maka dapat disimpulkan sebagai berikut. Kebutuhan siswa dan guru terhadap buku cerita anak berlatar kegiatan Kepramukaan Penggalang meliputi 1) buku cerita anak yang mengisahkan kegiatan-kegiatan yang terdapat dalam Pramuka Penggalang, 2) buku cerita anak dengan teks cerita yang beragam, (3) buku cerita anak dengan bahasa yang mudah dipahami oleh anak, 4) buku cerita anak dengan desain dan ilustrasi yang menarik.

Desain buku cerita anak berlatar kegiatan Kepramukaan Penggalang dirancang dengan menggunakan teori anatomi yang meliputi (1) bagian luar pada buku dan (2) bagian dalam pada buku. Bagian luar pada buku cerita anak berlatar kegiatan Kepramukaan Penggalang terdiri atas (1) sampul depan, (2) tulisan punggung dan (3) sampul belakang. Bagian dalam pada buku cerita anak terdiri atas (1) praisi, (2) isi, dan (3) pascaisi.

\section{DAFTAR PUSTAKA}

Arifin, Syamsul dan Adi Kusrianto. 2009. Sukses Menulis Buku Ajar dan Referensi Teknik dan Strategi Menjadikan Tulisan Anda Layak Diterbitkan. Jakarta: Grasindo.

Nurgiyantoro, Burhan. 2005. Sastra Anak: Pengantar Pemahaman Dunia Anak. Yogyakarta: Gadjah Mada University Press.

Permendikbud. 2015. Penumbuhan Budi Pekerti. Jakarta: Peraturan Menteri Pendidikan dan Kebudayaan.

Pusat Perbukuan. 2008. Pedoman Penulisan Buku Nonteks (Buku Pengayaan, Referensi, dan Panduan Pendidik). Jakarta: Depdiknas.

Sugihastuti. 2013. Tentang Cerita Anak. Yogyakarta: Pustaka Pelajar

Sugiyono. 2008. Metode Penelitian Pendidikan (pendekatan kuantitatif, kualitatif dan $R \& D)$. Bandung: ALFABETA.

Sukmadinata, Nana Syaodih. 2013. Metode penelitian pendidikan. Bandung: PT Remaja Rosda Karya. 
30 Fauziah \& Wagiran, Desain Buku Cerita Anak Berlatar Kegiatan Kepramukaan Penggalang

Sumardi. 2012. Kreatif Menulis Cerita Anak Bagaimana Menciptakan Cerita Anak yang Unggul. Bandung: NUANSA.

Wibowo, Ibnu Teguh. 2013. Belajar Desain Grafis. Yogyakarta: Buku Pintar. 